\title{
Fur Seals Return to Gough Island
}

\author{
W.R.P. Bourne
}

\begin{abstract}
After a somewhat perilous landing on Gough Island, south of Tristan da Cunha in the South Atlantic, the author was able to confirm the remarkable comeback of the fur seals there, once heavily exploited but now numbering over a hundred thousand.
\end{abstract}

In the 18 th century the increasingly affluent upper classes of Europe developed a taste for various Chinese products, such as tea and tableware, for which they could offer little in exchange, until it was realised that there was a good market in Canton for sealskins. Thereafter vessels trading to China used to leave gangs of sealers on the subantarctic islands to collect salted skins, until after some decades the seals were reduced to the point where the practice became unprofitable, and it was found more convenient to trade in opium instead. Eventually, about a century ago, the seals were left in peace again, and when in 1955-56 a British expedition visited Gough Island (220 miles SSE of Tristan da Cunha), to carry out surveys and set up a meteorological station, Michael Swales estimated that there were once more 13,000 Amsterdam fur-seals Arctocephalus tropicalis on the island. The future welfare of these seals was naturally a subject of interest when I was invited to join a party from the Percy Fitzpatrick Institute of African Ornithology accompanying the relief expedition visiting the meteorological station, now run by the South Africans, in October-November 1979.

Gough Island, in the central southern South Atlantic, is the eroded core of a late Tertiary volcano five to seven miles across and nearly $3000 \mathrm{ft}$ high. The centre of the island is occupied by a high bare plateau surrounded by steep slopes covered in fern-bush which terminate in grass-covered coastal cliffs overlooking narrow boulder beaches. The soil is still riddled everywhere with literally tens of millions of petrel burrows, because there is still no introduced predator larger than the house mouse (though even that appears to eat the smaller birds' eggs), and there are frequent groups of albatrosses and scattered pairs of predatory great skuas nesting on the ground. To reach them it is now once again necessary to wade through penguins and seals.

Previous accounts had prepared us for millions of rockhopper penguins and thousands of seals. It was difficult to check their numbers at first because we were landed in a net hauled by crane up a steep cliff that plunged into deep water. The next morning we climbed back down a rickety ladder before dawn to make a circuit of the island in the Hilary, the crayfishing boat which lives offshore, as she visited her strings of pots to collect what appeared to be several tons of catch and re-bait them with frozen fish from South Africa. All round the coast we could see penguin colonies in the grass at the top of the beach, but their numbers may have been over-estimated in the past, as Tony Williams thought that there were only a few hundred thousand. But we were hardly prepared to find the fur seals nearly as numerous, forming a continuous belt on the beaches scores of animals deep all round the island. It subsequently came as no surprise to discover that Dr M.N. Bester, of Pretoria University, has recently estimated that there are over 100,000 once again, as well as hundreds 

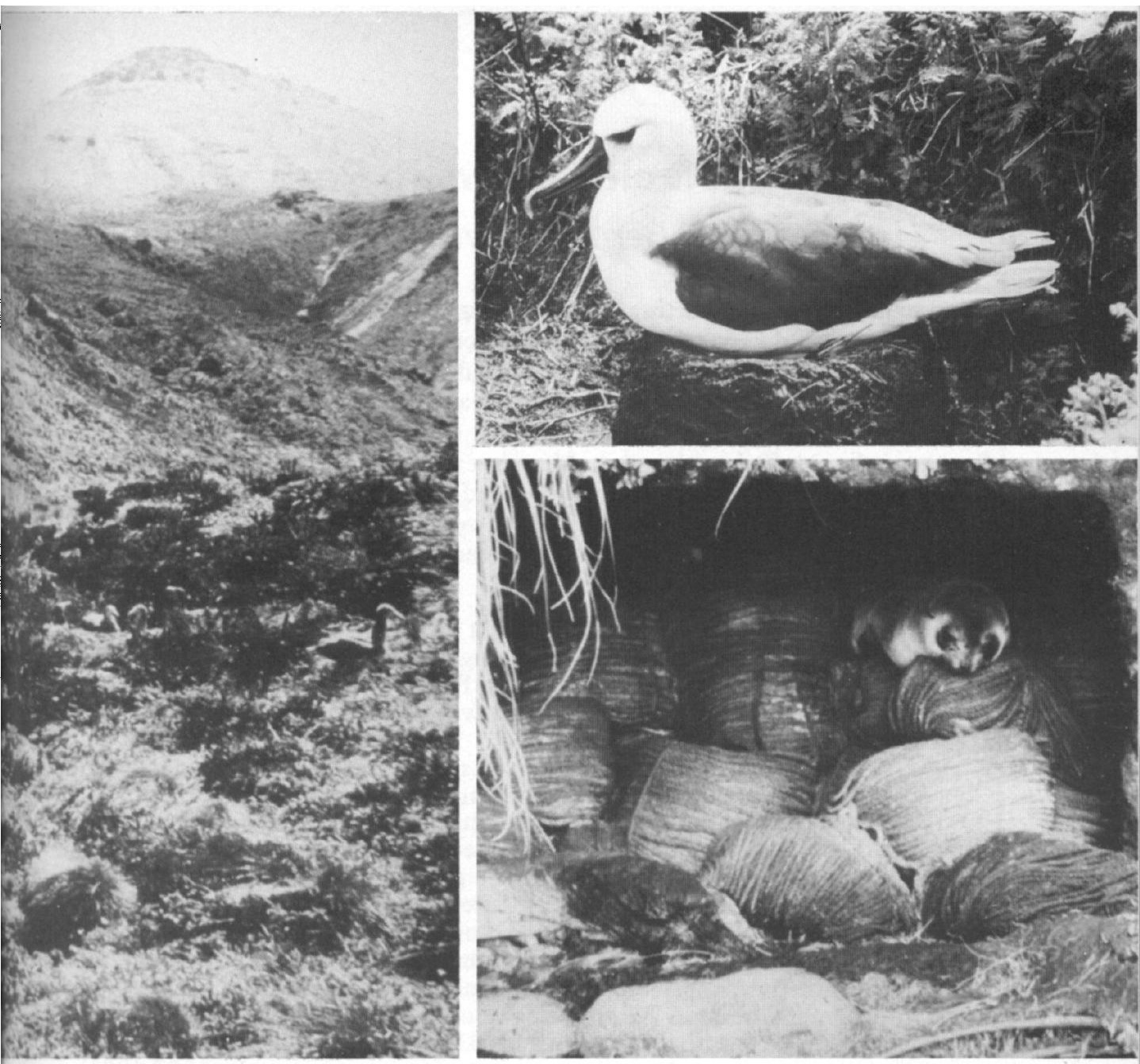

Left Giant petrel colony in low tree ferns on the edge of the open uplands M.K. Imber

Top right Yellow-nosed albatross on its nest

Bottom right A young fur seal in a sealers' cave now used as a store

of elephant seals, which stood out among them at intervals like large rocks.

We returned home to find that a furore had been provoked by an article in a Swiss newspaper, Der Bund, suggesting that the seals should be exploited again. While it is rather surprising that the article was taken seriously, it has revealed that the island, which is now a strong contender for the title of the most important seabird colony in the world, is still extraordinarily vulnerable. Cats on Marion Island introduced when another South African meteorological station was established there, are currently wiping out a similar seabird population. British authorities believe that control on Gough Island can safely be left in the hands of the Island Council of Tristan da Cunha, but many conservationists, worried at the potential dangers, would like to see the international movement take a more active interest in the whole archipelago.

Dr W.R.P. Bourne, Zoology Department, Aberdeen University, Tillydrone Avenue, Aberdeen. 